\title{
Recurrent Spindle Cell Sarcoma
}

National Cancer Institute

\section{Source}

National Cancer Institute. Recurrent Spindle Cell Sarcoma. NCI Thesaurus. Code C158430.

The reemergence of spindle cell sarcoma after a period of remission. 